\title{
Experimental and theoretical research on agitated contact drying of sewage sludge in a continuous paddle dryer
}

\author{
Shaoqing Chen ${ }^{a}$, Fei Wang ${ }^{a}$, Mathieu Milhéb ${ }^{b}$ Patricia Arlabosse ${ }^{b}$, Fenglin Liang ${ }^{b}$, Yong Chi ${ }^{a}$, Ange Nzihou ${ }^{b}$, and \\ Jianhua Yan ${ }^{a}$ \\ aState Key Laboratory of Clean Energy Utilization, Zhejiang University, Hangzhou, P. R. China; 'Université de Toulouse, Mines Albi, CNRS, \\ Centre RAPSODEE, Campus Jarlard, Albi, France
}

\begin{abstract}
Sludge drying is an important intermediate process for sewage sludge treatment, usage, and disposal. A series of drying experiments were conducted in a continuous paddle dryer in order to have a better understanding of the sludge drying mechanism. The couple model of penetration model and Markov chain was used to simulate the drying kinetics in a continuous paddle dryer. The drying process has been compared in experimental and theoretical results, which show good agreement. The sewage sludge drying process in a continuous paddle dryer can be divided into three stages: the pasty phase, the sticky phase, and the complete-granular phase. The influences of the drying parameters on the sludge drying kinetics in a continuous paddle dryer were investigated. The sludge flow rate, dryer wall temperature, and dryer slope have remarkable influence on sludge drying in the examined range, but the stirrer speed and steam temperature have little influence on the drying kinetics.
\end{abstract}

\section{KEYWORDS}

Continuous paddle dryer; drying kinetics; Markov chain; penetration model; sewage sludge

\section{Introduction}

With the development of the social economy, the amount of industrial and municipal wastewater discharge is increasing dramatically, especially in China. A lot of sludge were generated at the same time. In China, there were nearly 22 million tons of wet sludge produced every year until 2011, and it is still increasing significantly. According to the related statistics and forecasts, it is estimated that sludge annual production will exceed 60 million tons in 2020. ${ }^{[1]}$

Sewage sludge contain numerous harmful pathogenic micro-organisms, ${ }^{[2,3]}$ heavy metals, ${ }^{[4,5]}$ and organic pollutants. ${ }^{[6-8]}$ It has great potential impacts to the environment and human health. ${ }^{[2-8]}$ Currently, sludge treatment and disposal methods in China mainly consist of land filling, land utilization, building material utilization, and incineration. ${ }^{[9-11]}$ Sludge drying is an important intermediate process for sewage sludge treatment and disposal as it is able to reduce volume of sludge, weaken the odor of the product, and turn the sludge into solid state. ${ }^{[12-14]}$ However, sludge are a quite difficult material to dispose as it undergoes a sticky region when it is drying. ${ }^{[15]}$ The paddle dryer work well on sludge drying and the sludge viscosity is also well overcome by the paddle dryer. ${ }^{[16]}$ It has been widely used in industry. However, the researches on sludge drying are limited to empirical mode. So far, only a few articles about sludge theoretical model were published. ${ }^{[17-27]}$

The penetration model is the main method for the modeling of sludge drying in a paddle dryer. It was first proposed by Schlünder and coworkers ${ }^{[17-20]}$ for the drying of granular materials under vacuum condition or with inert gas condition. It was extended by Geyaudan and Andrieu ${ }^{[21]}$ and Farges et al. ${ }^{[22]}$ for the drying of hygroscopic materials. Arlabosse and Chitu, ${ }^{[23]}$ Deng et al., ${ }^{[24]}$ and Yan et al. ${ }^{[25]}$ used the theory for the modeling of sludge drying in a batchwise paddle dryer to analyze the contact drying of agitated sewage sludge with or without the presence of sweeping gas. However, the theory is limited to batchwise dryer. Few articles research on the modeling of sludge drying in a continuous dryer. Until recently, Milhé et al. ${ }^{[26]}$ developed the Markov chain model to simulate the sludge flow in a continuous paddle dryer. Moreover, Milhé et al. ${ }^{[27]}$ coupling the penetration model and Markov chain to model the sludge flow and heat transfer in a continuous dryer. 
In this study, a series of experiments were conducted to research the drying kinetics in a continuous paddle dryer with many operation parameters and to validate the couple model of the penetration model and Markov chain. Then, the couple model of the penetration model and Markov chain was also used as a theoretical method for further understanding the drying mechanism.

\section{Materials and methods}

\section{Sludge sample}

A kind of mechanically dewatered sewage sludge with water content between 80 and $83 \%$ (wet basis) was used in this study. The sludge were sampled from Albi city wastewater treatment plant $(60,000$ population equivalent) in France and were produced from mechanical dewatering of activated sludge which were produced through a biological-chemical nitrogen and phosphorus removal process for wastewater and an anaerobic digestion process for sludge. The results of the proximate analysis and ultimate analysis of dried sludge are showed in Table 1.

All the experiments were finished in 2 months. The sludge samples were stored in an airtight containers in a cold room at $4^{\circ} \mathrm{C}$ for over 2 days to weaken the influence of sludge age. ${ }^{[28]}$ Besides, all the experiments were completed in 2 weeks after sampling.

\section{Experimental setup}

Figure 1 shows the experimental setup of the sludge dryer. ${ }^{[29]}$ The pilot-scale dryer is constructed with a U-shape jacketed trough, 18 wedge-shaped paddles, and one hollow shaft. The trough is $1 \mathrm{~m}$ long and has an inner diameter of $0.16 \mathrm{~m}$. Scrapers is fixed to the trough to interact with the paddles. The diameter is $0.15 \mathrm{~m}$ for the paddles and $0.06 \mathrm{~m}$ for the shaft. The full contact area of the dryer is $1 \mathrm{~m}^{2}$. The paddles and shafts as well as the jacket of the shell walls were electrically heated during the drying process. The temperature in the shaft and jacket were measured and controlled by temperature sensors and a temperature controller. The

Table 1. Proximate and ultimate analyses of totally dried sludge.

\begin{tabular}{lrcc}
\hline Proximate analysis & $\begin{array}{c}\text { Sludge } \\
\text { (dry basis) }\end{array}$ & $\begin{array}{c}\text { Ultimate } \\
\text { analysis }\end{array}$ & $\begin{array}{c}\text { Sludge } \\
\text { (dry basis) }\end{array}$ \\
\hline Ash (\%) & 30.91 & $\mathrm{C}(\%)$ & 35.64 \\
Volatile (\%) & 59.01 & $\mathrm{H}(\%)$ & 5.51 \\
Fixed carbon (\%) & 10.08 & $\mathrm{~N}(\%)$ & 4.18 \\
Low heating value $(\mathrm{kJ} / \mathrm{kg})$ & 15179.98 & $\mathrm{~S}(\%)$ & 1.19 \\
Gross heating value $(\mathrm{kJ} / \mathrm{kg})$ & 16316.01 & $\mathrm{O}(\%)$ & 22.57 \\
\hline
\end{tabular}

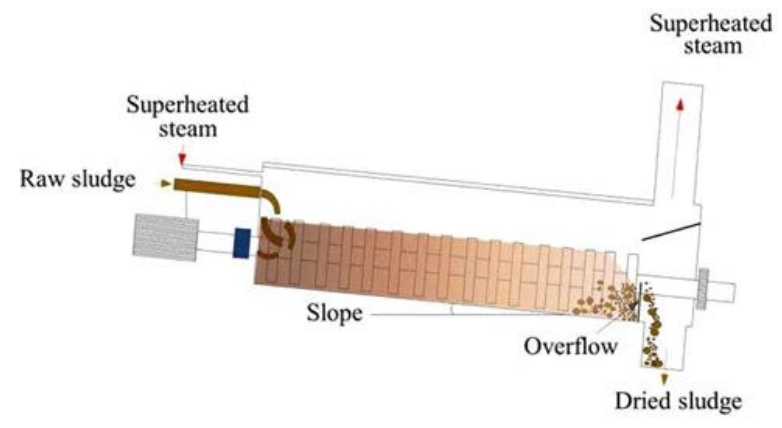

Figure 1. Scheme of the pilot-scale paddle dryer.

torque at the stirrer was measured by a torque dynamometer. The mass of the outlet dried sludge can be weighed continuously by a balance at the end of the dryer. The angle of the dryer can be changed in $\pm 5^{\circ}$, the stirrer speed can be adjusted from 10 to $60 \mathrm{rpm}$ and the overflow height is $113 \mathrm{~mm}$. More details of the dryer can be found in a previous article. ${ }^{[29]}$

In the sewage sludge drying experiment, the raw sludge were continuously supplied to one end of the dryer by a 401 Moineau pump and was dried while being transferred to the other end. When the height of the sludge mass at the discharge end was higher than the overflow height, the dried sludge were discharged to an airtight tank. Water evaporated during the drying process was extracted outside the dryer with sweeping gas (superheated steam) by an induced fan and wet air was condensed and then treated with an off-gas treatment system. In addition, the basic conditions of the sweeping gas were $1 \mathrm{~atm}$ for steam pressure, $1.1 \mathrm{~kg} / \mathrm{h}$ for steam flow rate, and $160^{\circ} \mathrm{C}$ for steam temperature.

When the outlet mass flow rate and the torque were stable, named a steady state $\mathrm{e}^{[30,31]}$ was arrived during the drying process, 18 samples of sludge along the dryer were sampled for the measurement of the moisture content of sludge along the dryer. In addition, when the experiment was finished, the dryer would be stopped and the outlet and inlet of the dryer would be closed for the dryer to be cooled down. Then all the sludge in the dryer would be recovered to get the mass of dry solid holdup of the dryer in a steady state.

\section{Model description}

\section{Penetration model}

The penetration model was used to simulate heat transfer during contact drying of agitated sewage sludge in the dryer. 


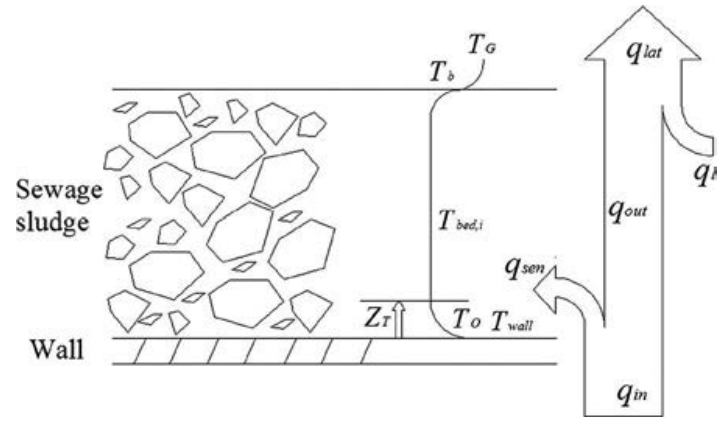

Figure 2. The temperature profiles and heat fluxes during the contact period.

In the model, ${ }^{[17-19]}$ the steady-state mixing process is replaced by a sequence of discrete mixing steps. A contact period with a fictitious time length of $t_{\mathrm{R}}$ is followed by an instantaneous perfect macromixing of the bulk. During the contact period, the bulk is assumed to be static on the heating surface to be heated by conduction. Figure 2 shows the temperature profiles and heat fluxes during the contact period.

First of all, we assumed that sludge in paste phase can be considered as a saturated monodispersed particulate phase $^{[21,23]}$ so that the theory can be used for the entire process of sludge drying. According to Fig. 2, the total heat transfer resistance of sludge drying $\left(1 / h_{\text {total }}\right)$ consists of the contact surface resistance $\left(1 / h_{\mathrm{ws}}\right)$ and the penetration resistance of the sludge bulk $\left(1 / h_{\mathrm{sb}}\right)$. The contact surface resistance can be calculated according to Schlünder and Mollekopf. ${ }^{[17]}$

The penetration resistance of the sludge bulk can be calculated by Eq. $(1)^{[17,23]}$ :

$$
h_{\mathrm{sb}}=2 \sqrt{\frac{(\rho \lambda c)_{\mathrm{b}}}{\pi t_{\mathrm{R}}}} \times \frac{1}{\operatorname{erf}(\zeta)}
$$

where $\rho_{\mathrm{b}}, \lambda_{\mathrm{b}}, c_{\mathrm{b}}, t_{\mathrm{R}}$, and $\zeta$ are the density of dry bed, the effective thermal conductivity of dry bed, the specific heat of dry bed, the contact time, and the nondimensional drying front position, respectively.

The contact time $t_{\mathrm{R}}$ can be calculated as follows ${ }^{[17]}$ :

$$
t_{\mathrm{R}}=\frac{N_{\mathrm{mix}}}{n}
$$

where $N_{\text {mix }}$ and $n$ are the mixing number and the stirrer speed.

For paddle dryers, the mixing number $N_{\text {mix }}$ can be calculated as follows ${ }^{[17]}$ :

$$
N_{\text {mix }}=9 \mathrm{Fr}^{0.05}
$$

where $F r$ is the Froude number.
The nondimensional drying front position $\zeta$ is the solution of Eq. $(4)^{[17]}$ :

$$
\begin{aligned}
& \zeta \cdot \exp \left(\zeta^{2}\right) \cdot\left[1+\frac{\sqrt{\pi}}{2} \cdot \sqrt{\frac{\mathrm{h}_{\mathrm{ws}}^{2}}{(\lambda \rho c)_{\mathrm{b}}} t_{\mathrm{R}}} \cdot \operatorname{erf}(\zeta)\right] \\
& =\frac{1}{2} \sqrt{\frac{\mathrm{h}_{\mathrm{ws}}^{2}}{(\lambda \rho)_{\mathrm{b}}} t_{\mathrm{R}}} \cdot \frac{c_{\mathrm{b}} \cdot\left(T_{\mathrm{w}}-T_{\text {bed, } \mathrm{i}}\right)}{X_{\mathrm{i}} \cdot \Delta H_{\text {total }}}
\end{aligned}
$$

where $\Delta H_{\text {total }}, T_{\mathrm{w}}$, and $T_{\mathrm{bed}, i}$ are the total heat of sorption of sludge, the wall temperature, and the sludge bulk temperature, respectively.

Finally, the total heat transfer resistance of sludge drying $1 / h_{\text {total }}$ is given by Eq. (5):

$$
\frac{1}{h_{\text {total }}}=\frac{1}{h_{\mathrm{ws}}}+\frac{1}{h_{\mathrm{sb}}}
$$

Assuming that there is no heat transfer between dry and wet particles during the instantaneous perfect macromixing, ${ }^{[17,19,23]}$ the drying rate $m_{\mathrm{V}}$ and the sludge bulk average temperature increase during a contact period $\Delta T_{\text {bed, } i}$ can be calculated as follows, respectively ${ }^{[17]}$ :

$$
\begin{gathered}
m_{\mathrm{V}}=\frac{h_{\text {total }} \cdot \mathrm{e}^{-\zeta^{2}} \cdot\left(T_{\mathrm{w}}-T_{\text {bed }, i}\right)}{\Delta H_{\text {total }}} \\
\Delta T_{\text {bed }, i}=\frac{\Delta H_{\text {total }}}{c_{\mathrm{p}}+X \cdot c_{\mathrm{w}}} \cdot \frac{1-\mathrm{e}^{-\zeta^{2}}}{\mathrm{e}^{-\zeta^{2}}} \cdot \Delta X
\end{gathered}
$$

where $X$ and $\Delta X$ are moisture content and the decrement of moisture content of sludge during a contact period. $c_{\mathrm{w}}$ is the specific heat of water. $\Delta H_{\text {total }}$ can be calculated according to the previous articles. ${ }^{[23,32]}$

\section{Modeling of sludge flow by Markov chain}

Modeling of sludge flow in a continuous dryer by Markov chain was developed by Milhé et al. ${ }^{[26]}$ According to Charlou et al., ${ }^{[30]}$ water and dry solids have the same residence time distribution. Thus, in the theory of Markov model, ${ }^{[26]}$ the water and dry solids flow in a continuous dryer is modeled by one Markov chain. Figure 3 shows the Markov chain of sludge flow and $M$ represents the mass flow rate of the dry solids. The Markov chain consists of $n$ cells, which are supposed to be a continuous stirred tank reactor, corresponding to the number of paddles. According to Tazaki et al., ${ }^{[33]}$ back mixing of sludge occurs when sludge is drying. Therefore, for each cell, the theory assumes that part of the sludge will flow forward, while the other part will stay in the cell or move backward due to the action of the paddles. The recycling of sludge flow can be defined by the coefficient $R$ which is the ratio of the backward sludge flow to the overall sludge flow. At the end of 


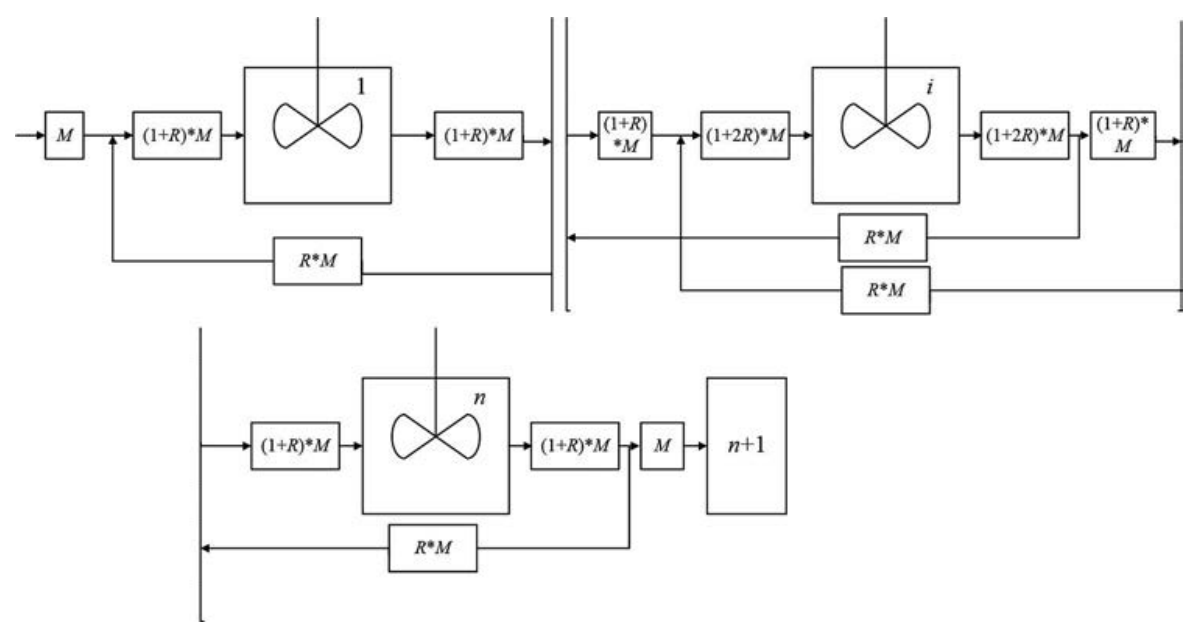

Figure 3. Markov chain of sludge flow.

the chain, the $(n+1)$ th cell is used as an absorbing cell for the collecting of dried sludge which represents the dryer outlet.

In the theory of Markov model, ${ }^{[26]}$ the evolution of state vector $\boldsymbol{S}=\left[\begin{array}{lllll}S_{1} & S_{2} & \ldots & S_{n} & S_{n+1}\end{array}\right]^{\mathrm{t}}$ (such as mass of water) is controlled by a matrix of transition probabilities $\boldsymbol{P} . \boldsymbol{P}$ is a tridiagonal matrix as the transition time $\Delta t$ is short enough so that the sludge can only stay in the cell or move to the directly connected cell. $\boldsymbol{P}$ can be described as follows ${ }^{[26]}$ :

$\boldsymbol{P}=\left[\begin{array}{ccccccc}P_{1,1} & P_{1,2} & \ldots & \ldots & 0 & 0 & 0 \\ P_{2,1} & P_{2,2} & P_{2,3} & \ldots & \ldots & 0 & 0 \\ 0 & P_{3,2} & \ldots & P_{i-1, i} & 0 & \ldots & 0 \\ \ldots & \ldots & \ldots & P_{i, i} & \ldots & \ldots & \ldots \\ 0 & \ldots & 0 & P_{i+1, i} & \ldots & P_{n-1, n} & 0 \\ 0 & 0 & \ldots & \ldots & P_{n, n-1} & P_{n, n} & 0 \\ 0 & 0 & 0 & \ldots & 0 & P_{n+1, n} & P_{n+1, n+1}\end{array}\right]$

where $P_{i, j}$ means the transition probability from cell $j$ to cell $i$. The calculation of $P_{i, j}$ can be acquired from the previous article. ${ }^{[26]}$

Thus, the evolution of state vector $S$ can be calculated as follows ${ }^{[26,27]}$ :

$$
\boldsymbol{S}(t+\Delta t)=\boldsymbol{P} \times\left(\boldsymbol{S}(t)+\boldsymbol{S}_{\text {feed }}\right)
$$

where $S_{\text {feed }}$ is the vector for feeding of $S$ introduced in the dryer during the transition time $\Delta t$.

The transition probability $P_{i, j}$ is controlled by the recycling coefficient $R$, the holdup of one cell $H u$, and the transition time $\Delta t{ }^{[26]}$ In the previous article, ${ }^{[26]}$ the recycling coefficient $R$ is considered to be constant as a first attempt and the value of $R$ is estimated to be in the range of $2-5$. In this range, the value of $R$ has a small influence on the simulation of sludge flow. Thus, the value of $R$ is set as 3. The $H u$ is also considered to be constant as a first attempt. Therefore, the $H u$ is equal to the experimental result of holdup of the dryer divided by the number of cells. In addition, the fictitious time of $t_{\mathrm{R}}$ of penetration model is chosen as the transition time $\Delta t$ of Markov chain, which allowed a simple algorithm for the modeling of sludge flow and heat transfer in a continuous dryer by coupling penetration model and Markov chain. ${ }^{[26,27]}$

\section{Coupling model of penetration model and Markov} chain

Modeling of sludge flow and heat transfer in a continuous dryer by coupling model of penetration model and Markov chain was developed by Milhé et al. ${ }^{[27]}$

Since both penetration model and Markov chain are discrete algorithm and they share a same time duration $t_{\mathrm{R}}$, a simple algorithm of coupling penetration model, and Markov chain can be used. ${ }^{[27]}$ A state at time $t_{0}$ with known water content, solid holdup, enthalpy, and temperature of sludge bulk of each cell was used as an initial state. Moreover, as sludge temperature increases rapidly after its introduction in the dryer, modeling the sludge heating is not critical for process description. Therefore, sludge heating was neglected in the first attempt and initial sludge temperature is supposed to be $100^{\circ} \mathrm{C}$.

During the contact period with a fictitious time length of $t_{\mathrm{R}}$, penetration model can be used to calculate the water content, temperature, enthalpy, and drying 
rate of sludge bulk for each cell at time $t+t_{\mathrm{R}}$ from these at time $t$. Then, Markov chain can be used to calculate a new distribution of water content and dry solid of sludge bulk with the matrix of transition probabilities $\boldsymbol{P}$ during the period of instantaneous perfect macromixing of the bulk. The new enthalpy and temperature of sludge bulk can also be acquired by the new water content and dry solid of sludge bulk. Therefore, the water content, temperature, and enthalpy of sludge bulk can be calculated through the iterative algorithm until the changes of moisture content and temperature of sludge bulk is small enough as in Eq. (10). ${ }^{[27]}$ Finally, the steady state is considered to be arrived.

$$
|S(t)-S(t-\tau)| \leq 0.001
$$

The simple scheme of the coupling model of penetration model and Markov chain is shown in Fig. 4. $X(t), X(t-\tau)$ are the moisture content of sludge bulk for each cell at time $t$ and $t-\tau$, respectively. $T_{\text {bed,i }}(t)$, $T_{\text {bed,i }}(t-\tau)$ are the temperature of sludge bulk for each cell at time $t$ and $t-\tau$, respectively. More details of the coupling model of penetration model and Markov chain can be found in a previous article. ${ }^{[27]}$

\section{Determination of the sludge parameters}

Since the sludge used in this article is same as the sludge in the previous articles, ${ }^{[23,27]}$ the same parameters of sludge in the previous articles ${ }^{[23,27]}$ were adapted in this

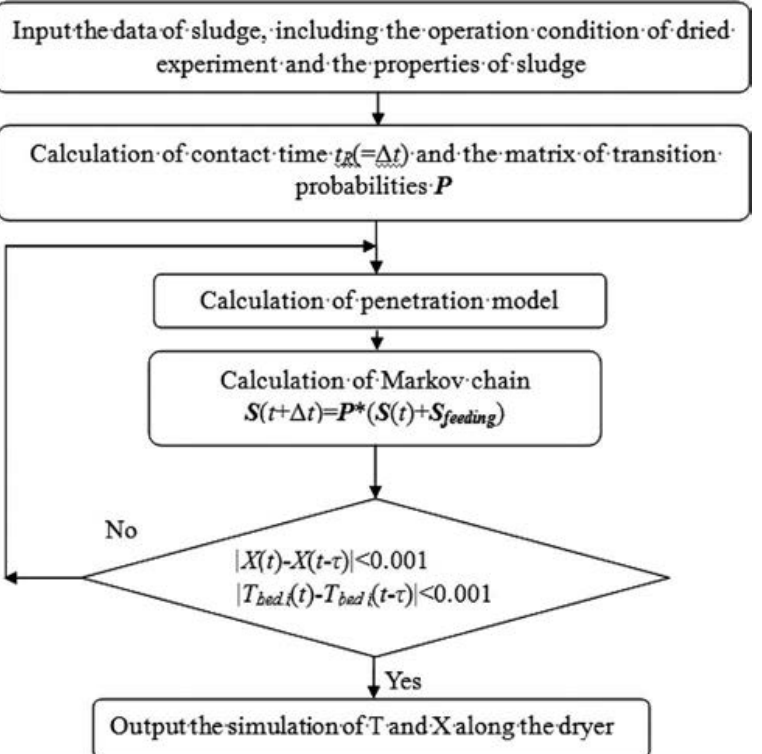

Figure 4. The simple scheme of the coupling model of penetration model and Markov chain.

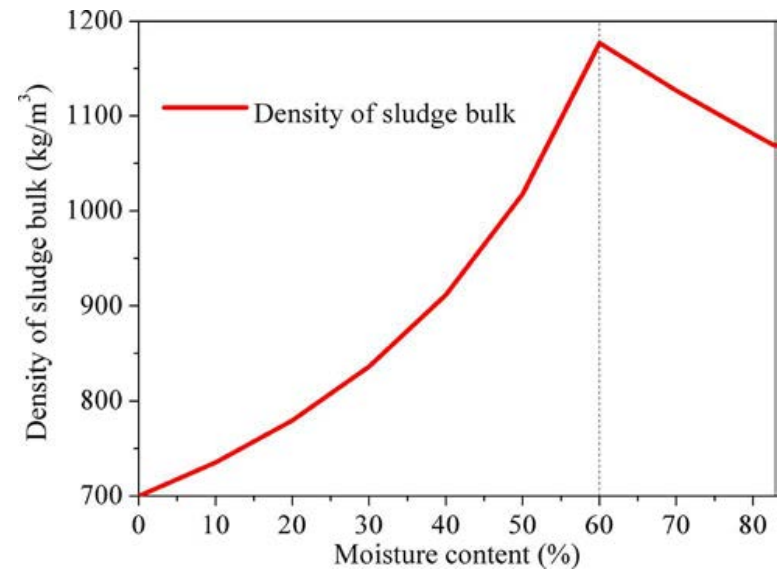

Figure 5. The density of sludge bulk with different moisture contents.

article. The density of sludge bulk with different moisture contents is shown in Fig. 5.

\section{Results and discussion}

\section{Sewage sludge drying description}

The typical experimental and simulated results of sludge drying in a continuous dryer are shown in Fig. 6 . Figure $6 \mathrm{a}$ gives the comparison of the experimental and simulated moisture content along the dryer. The parameters of the experiment are shown in Fig. 6 . Figure 6 a shows clearly that the experimental and calculated moisture content curves are in good agreement.

As part of sludge will flow backward in the dryer, the calculation of the experimental drying rate for each cell will be the results of a complicated linear equation group with 18 parameters instead of simple calculations between neighboring cells. And the results will be significantly influenced by the fluctuations of slopes of the moisture content curve along the dryer which is caused by the measurement error of moisture content. Thus, the calculated experimental drying rate for each cell will be quite different from the real drying rate for each cell and will be meaningless for analysis of sludge drying mechanism. Above all, the simulated drying rate will be used for analysis. Figure $6 \mathrm{~b}$ shows the simulated total drying rate and drying rate per unit contact area of each cell along the dryer. to further understand the sludge drying mechanism in a continuous paddle dryer, the drying rate and moisture content of each cell, which corresponds to each paddle, are extracted to form new curves. Figure $6 c$ and $6 d$ shows the simulated drying rate per unit contact area and simulated total drying rate 

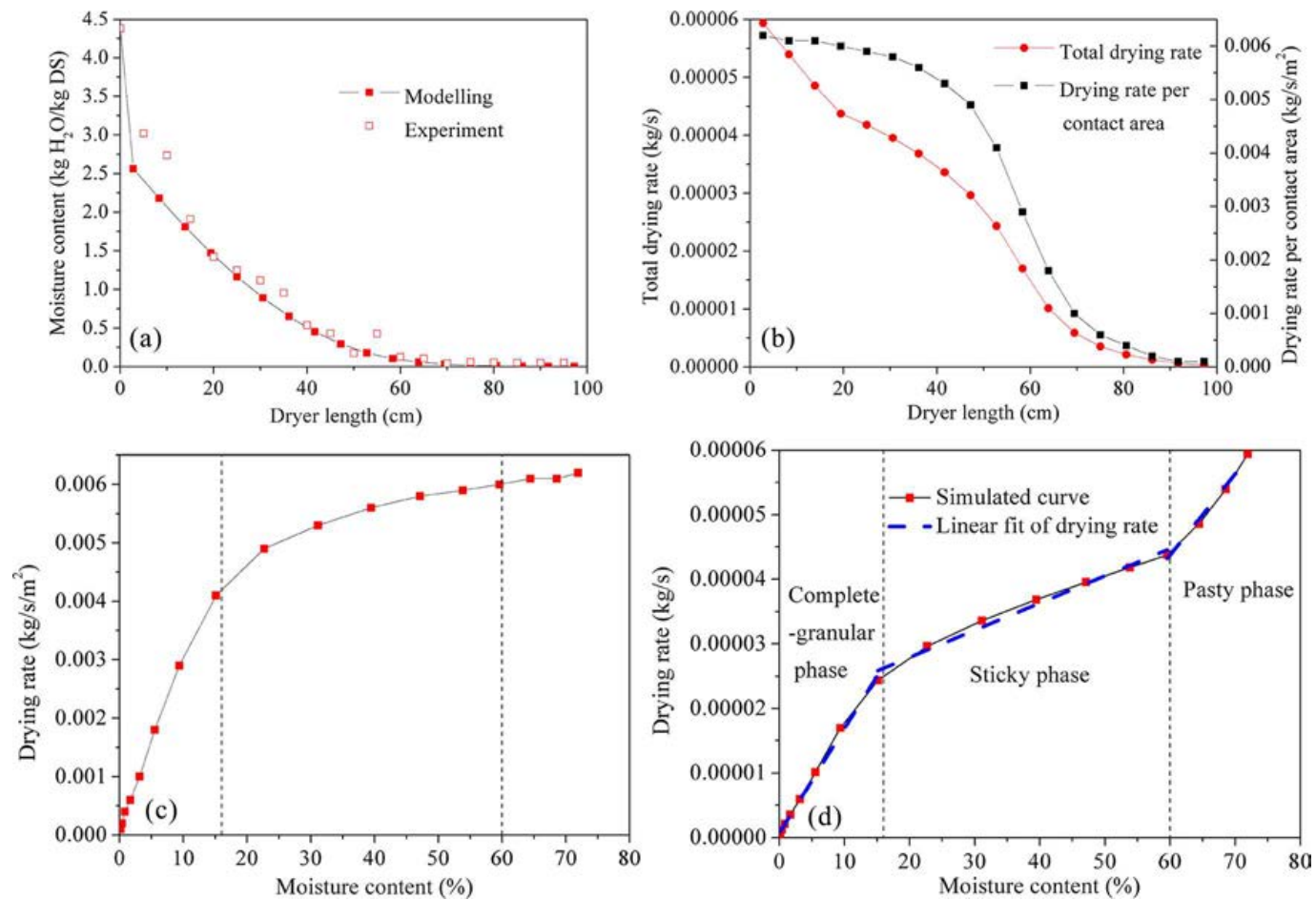

Figure 6. The typical experimental and simulated results of sludge drying in a continuous dryer (sludge flow rate: $2 \mathrm{~kg} / \mathrm{h}$, dryer slope: $3^{\circ}$, dryer wall temperature: $160^{\circ} \mathrm{C}$, stirrer speed: $42 \mathrm{rpm}$, steam temperature: $160^{\circ} \mathrm{C}$ ). (a) Comparison of experimental and simulated moisture contents along the dryer, (b) simulated drying rate of each cell along the dryer, (c) simulated drying rate of each cell per unit contact area against the moisture content, and (d) simulated drying rate of each cell against the moisture content.

of each cell against the moisture content of sludge bulk in each cell, respectively.

Figure $6 \mathrm{~d}$ indicates the sludge drying process in a continuous dryer can be separated into three stages: the pasty phase $(83-60 \%$, wet basis), the sticky phase (60-16\%, wet basis), and the complete-granular phase (16-0\%, wet basis) according to the slopes of the different phases in the drying rate curve. At the beginning of the pasty phase, the pasty sludge with a moisture content of about $81 \%$ is introduced into the dryer. When the sludge moves forward along the dryers, the water will be evaporated and the moisture content will decrease. The sludge bulk will shrink fast for the reasons of mass loss and increase in sludge density (Fig. 5). The contact area for heat transfer will also correspondingly decrease fast. Thus, the total drying rate of each cell will decrease fast in the pasty phase. When the moisture content further decreases along the dryer, the sludge becomes sticky and granulation occurs during the sticky phase. Correspondingly, the heat transfer coefficient for sludge drying decreases, sludge bulk shrinks in a relatively slow way, and the contact area of sludge bulk also decreases slowly. Besides, a decrease in moisture content will also cause a little decrease in drying rate per unit contact area because of the total heat of sorption of sludge (Fig. 6c). Thus, the total drying rate of each cell will decrease in a relatively slow way in the sticky phase. When the moisture content is lower than $16 \%$, almost all the sludge have been in granular phase. The water in the sludge is hard to be evaporated as a very high total heat of sorption is needed (Fig. 6c). The contact area of sludge bulk is also decreasing. And the total drying rate of each cell will decrease in a fast way in the complete-granular phase. It is unreasonable to dry sludge in the granular phase.

The main parameters influencing the moisture content along the dryer and sludge drying rate are sludge flow rate, dryer wall temperature, stirrer speed, dryer slope, and steam temperature. Experiments and simulations were performed to determine the effects of these parameters for sludge drying in a continuous dryer.

\section{Influence of sludge flow rate}

To determine the influence of sludge flow rate on the sludge drying process, three experiments were performed with different sludge flow rates ( 2 and $4 \mathrm{~kg} / \mathrm{h}$ ). As shown in Fig. 7a, the experimental results of 

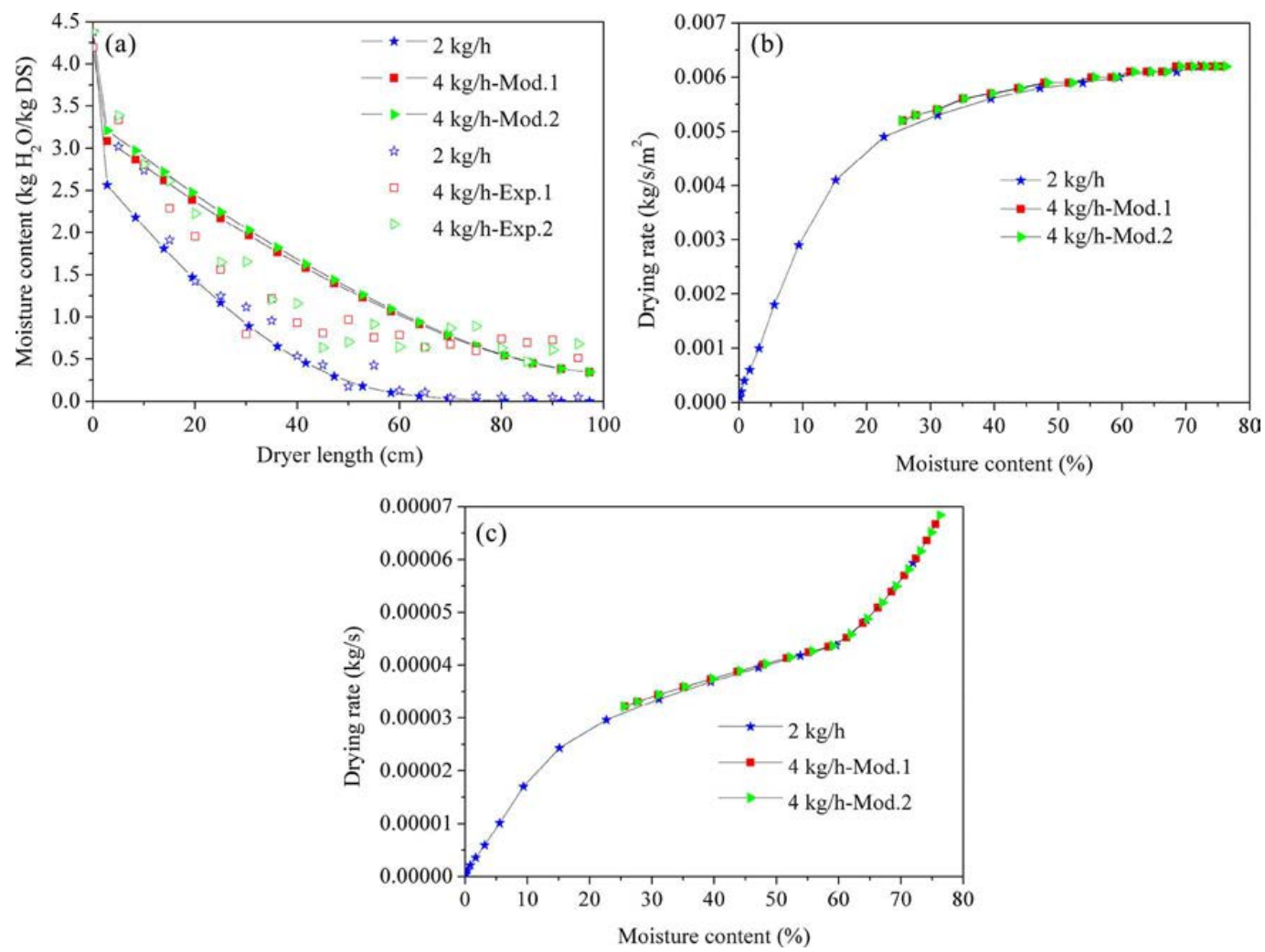

Figure 7. The experimental and simulated results of sludge drying in a continuous dryer with different sludge flow rate (sludge flow rate: 2 and $4 \mathrm{~kg} / \mathrm{h}$, dryer slope: $3^{\circ}$, dryer wall temperature: $160^{\circ} \mathrm{C}$, stirrer speed: $42 \mathrm{rpm}$, steam temperature: $160^{\circ} \mathrm{C}$ ). (a) Comparison of experimental and simulated moisture contents along the dryer, (b) simulated drying rate of each cell per unit contact area, and (c) simulated drying rate of each cell.

moisture for higher sludge flow rates are decreasing faster but ending up to a bit higher level than the calculated results with higher flow rate of sludge. The holdup of each cell (paddle) we used for calculation is considered to be constant as a first attempt. However, from the phenomena of the experiments for higher sludge flow rates, we find that the holdup of the cells in front of the dryer was higher than that in the end of the dryer. A higher/lower holdup will result in a higher/lower contact area of sludge bulk in each cell. Thus, the experimental drying rate is higher in the front part but lower in the latter part than the calculated results with higher flow rate of sludge. And the actual moisture content will decrease faster but end up to a bit higher level than the calculated results. For the experiments of lower sludge flow rates, the differences between the holdups of the cells in different parts of the dryer are not too big. Therefore, the experimental and calculated moisture content curves along the dryer with different sludge flow rate are in good agreement. Generally, the experimental and calculated moisture content curves along the dryer with different sludge flow rates are in good agreement within the scope of the research. The two experiments with the same operation condition (sludge flow rate: $4 \mathrm{~kg} / \mathrm{h}$ ) show that the experiments have a good repeatability.

There is more water needed to be evaporated when the sludge flow rate is higher. However, the drying rate per unit contact area and total drying rate of each cell don't change with the same water content for the different sludge flow rate which is shown in Fig. $7 b$ and $7 c$. Thus, the sludge with a lower sludge flow rate will be dried faster than that with a higher sludge flow rate.

\section{Influence of dryer wall temperature}

To analyze the influence of dryer wall temperature on the sludge drying process, three experiments were performed with different dryer wall temperatures (140, $160,180^{\circ} \mathrm{C}$ ). Ignoring the measurement error of sludge moisture content, the experimental moisture content curve with different dryer wall temperatures is in good agreement with the simulated curve, which is shown in Fig. 8a. 

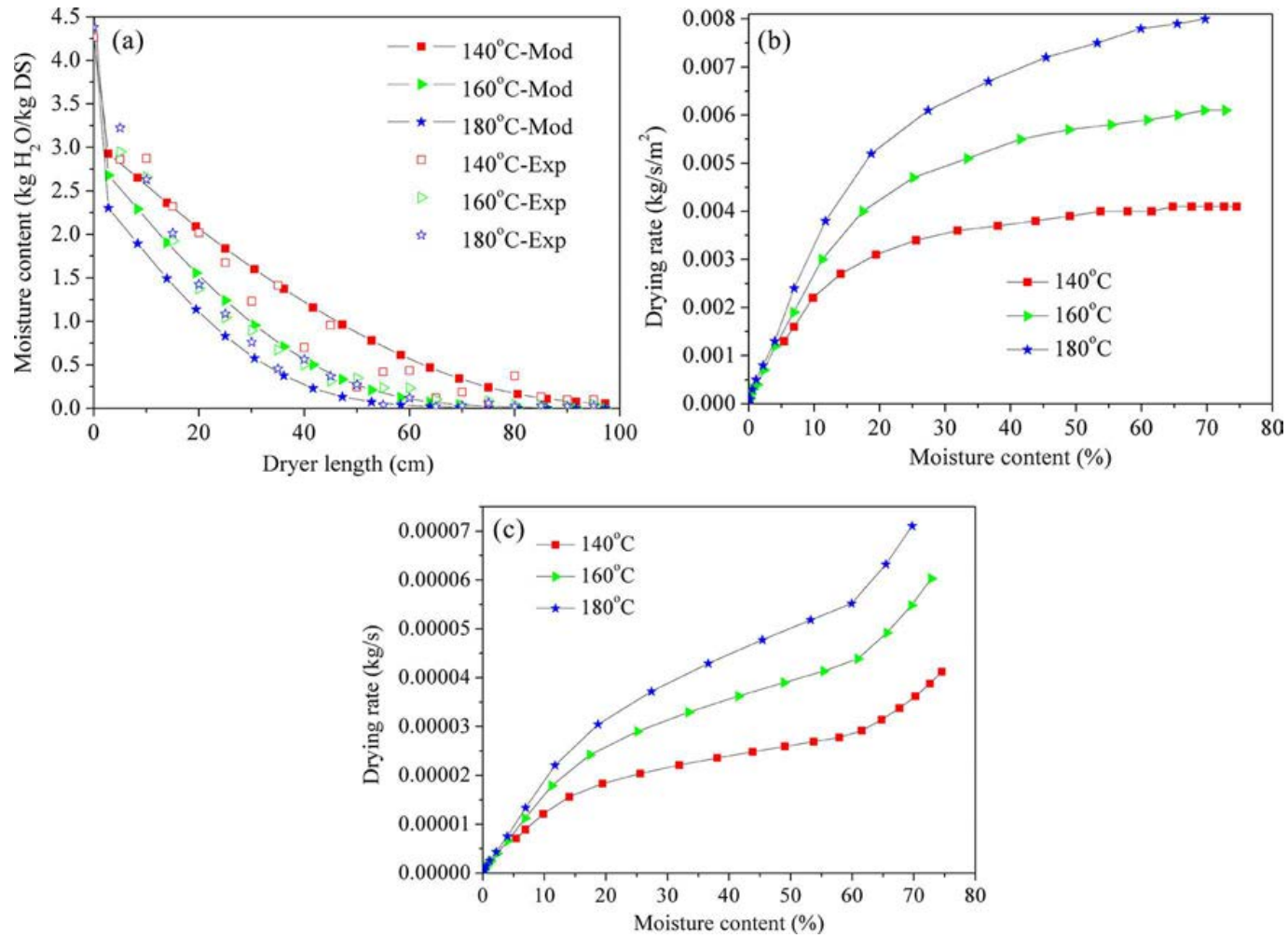

Figure 8. The experimental and simulated results of sludge drying in a continuous dryer with different dryer wall temperature (dryer wall temperature: 140,160 and $180^{\circ} \mathrm{C}$, sludge flow rate: $2 \mathrm{~kg} / \mathrm{h}$, dryer slope: $3^{\circ}$, stirrer speed: $28 \mathrm{rpm}$, steam temperature: $160^{\circ} \mathrm{C}$ ). (a) Comparison of experimental and simulated moisture contents along the dryer, (b) simulated drying rate of each cell per unit contact area, and (c) simulated drying rate of each cell.

Figure $8 \mathrm{~b}$ and $8 \mathrm{c}$ shows the drying rate per unit contact area and total drying rate of each cell with a higher dryer wall temperature are higher than these with a lower dryer wall temperature. This is because that a higher dryer wall temperature will cause a higher thermodynamic temperature difference for heat transfer. Therefore, the sludge with a higher dryer wall temperature will be dried faster than that with a lower sludge flow rate.

\section{Influence of stirrer speed}

The influence of stirrer speed on sludge drying is examined for two different stirrer speeds of 28 and $42 \mathrm{rpm}$. The experimental and simulated moisture content curves with different stirrer speed are shown in Fig. 9a. The experimental and simulated moisture content curves are in good agreement with the curve, especially when the moisture content is lower than $2.25 \mathrm{~kg} \mathrm{H}_{2} \mathrm{O} / \mathrm{kg}$ DS (dry solid).

The simulated drying rate per unit contact area and simulated total drying rate of each cell are shown in Fig. $9 \mathrm{~b}$ and $9 \mathrm{c}$, respectively. The results indicate that both the experimental data and calculated data of moisture content, drying rate per unit contact area and total drying rate don't show clear difference between different stirrer speeds. Schlünder and Mollekopf $^{[17]}$ and Arlabosse and Chitu ${ }^{[23]}$ identified a critical contact time below in which an increase in stirrer speed won't influence sludge drying and the critical contact time ( $\left.t_{\text {critical }}\right)$ is given as follows:

$$
\mathrm{t}_{\text {critical }}=\frac{4 \cdot(\rho \lambda c)_{\mathrm{b}}}{\pi \cdot h_{\mathrm{ws}}^{2}}
$$

As the parameters of the sludge and dryer are known, Eq. (11) allows calculation of the critical stirrer speed. Thus, the value of the critical stirrer speed is $20 \mathrm{rpm}$ which is lower than the examined range (28-42 rpm). Therefore, the experimental and theoretical results, stirrer speed has little influence on the sludge drying in the examined range.

\section{Influence of dryer slope}

Three experiments were conducted with different dryer slopes $\left(1^{\circ}, 3^{\circ}, 5^{\circ}\right)$ to research the influence of dryer slope on sludge drying. Generally, Fig. 10a shows the 

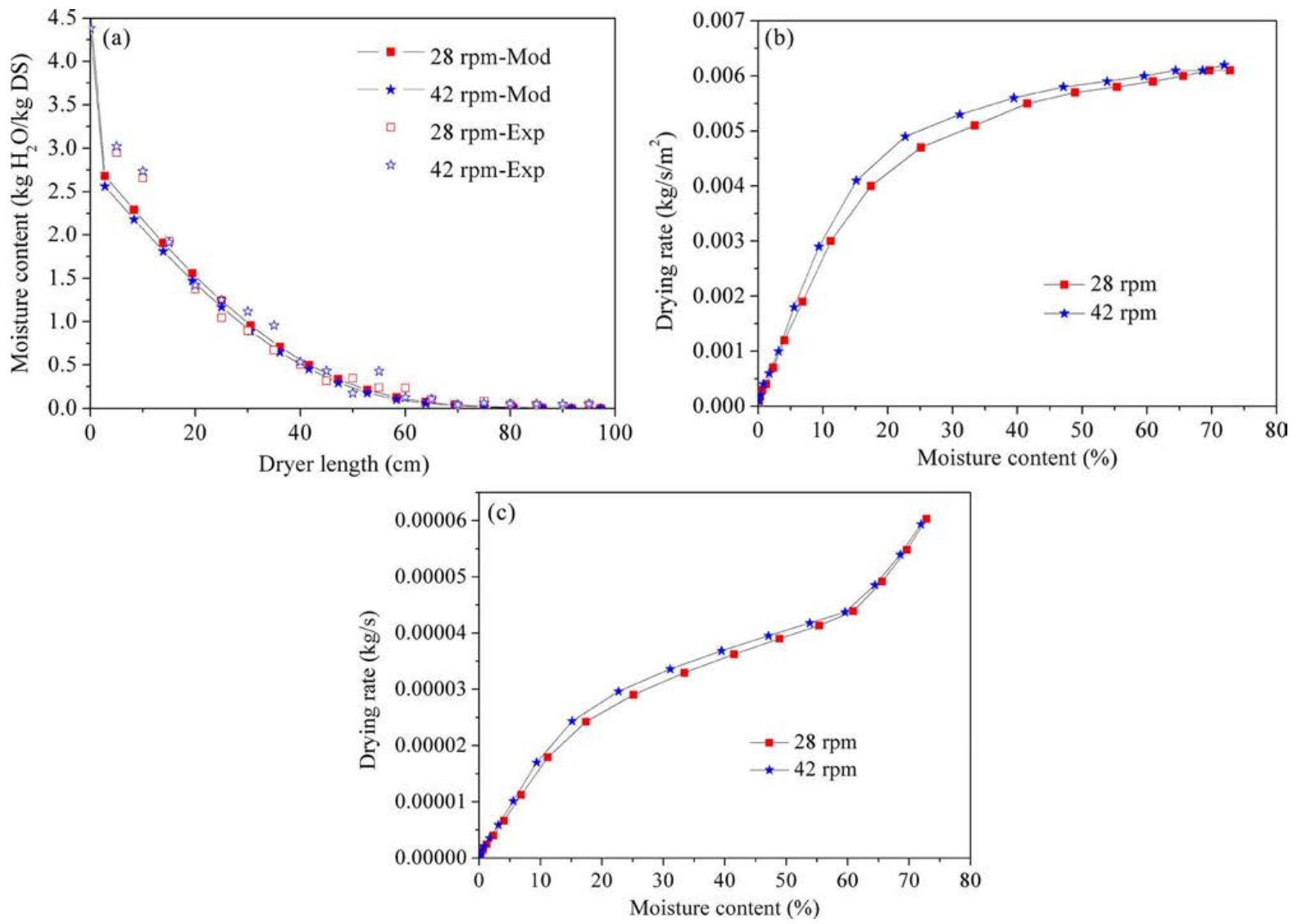

Figure 9. The experimental and simulated results of sludge drying in a continuous dryer with different stirrer speeds (stirrer speed: 28 and $42 \mathrm{rpm}$, sludge flow rate: $2 \mathrm{~kg} / \mathrm{h}$, dryer slope: $3^{\circ}$, dryer wall temperature: $160^{\circ} \mathrm{C}$, steam temperature: $160^{\circ} \mathrm{C}$ ). (a) Comparison of experimental and simulated moisture contents along the dryer, (b) simulated drying rate of each cell per unit contact area, and (c) simulated drying rate of each cell.

experimental and simulated moisture content curves are in good agreement within a satisfactory range. However, the simulated and experimental results are not in good agreement in the end of drying when the dryer slope is $1^{\circ}$ or $5^{\circ}$. When the sludge are drying, there will be some water condensed at the end part of the dryer. When the dryer slope is $1^{\circ}$, there will be more sludge in the dryer, more water evaporated and more water condensed at the end part of the dryer. Therefore, the water will fall on the dried sludge and then the moisture content of the sludge at the end part of the dryer will increase. And while the dryer slope is $5^{\circ}$, the water will also fall on the sludge as the slope of the dryer is too high. That is why, the experimental results are higher than the simulated results at the end of drying with $1^{\circ}$ and $5^{\circ}$.

Figure $10 \mathrm{~b}$ indicates that the drying rate per unit contact area is not influenced by dryer slope. However, the holdup increases while the dryer slope decreases and the increased holdup will increase the contact area of sludge bulk in each cell. Therefore, the total drying rate of each cell increases with the decrease in dryer slope, which is shown in Fig. 10c. And the sludge are dried faster when the dryer slope is lower.

\section{Influence of steam temperature}

To identify the influence of steam temperature on the sludge drying process, two experiments were performed with different steam temperatures $\left(140,160^{\circ} \mathrm{C}\right)$. The experimental moisture content curves are also shown in Fig. 11. As the steam temperature has not been considered in the model used in this article, there is no simulation result for different steam temperatures. However, the moisture content curves along the dryer with different steam temperatures are almost the same. Therefore, steam temperature has little influence in the range of $140-160^{\circ} \mathrm{C}$ on sludge drying and can be neglected during the simulation of sludge drying in a continuous dryer. 

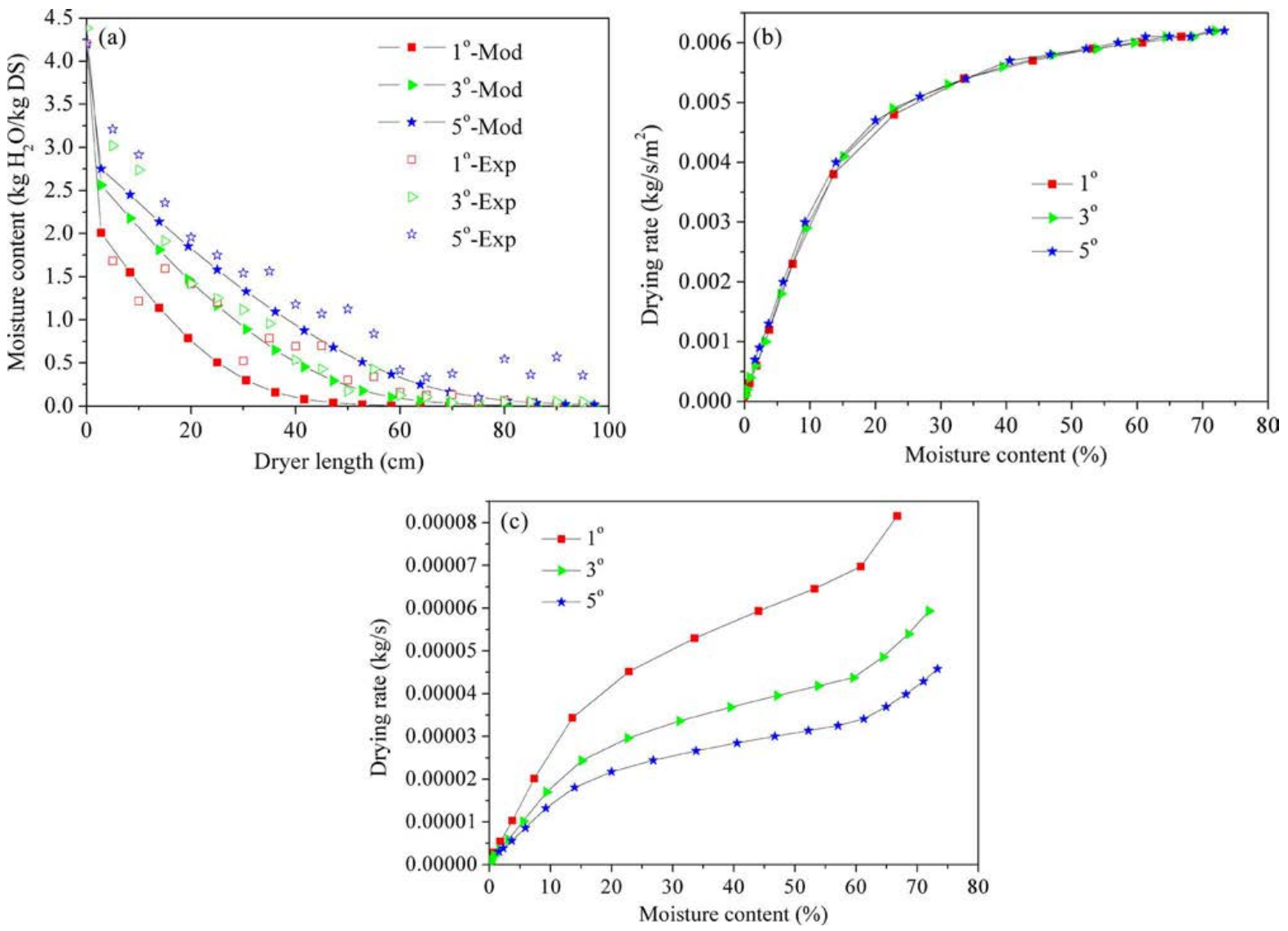

Figure 10. The experimental and simulated results of sludge drying in a continuous dryer with different dryer slopes (dryer slope: $1^{\circ}$, $3^{\circ}$ and $5^{\circ}$, sludge flow rate: $2 \mathrm{~kg} / \mathrm{h}$, dryer wall temperature: $160^{\circ} \mathrm{C}$, stirrer speed: $42 \mathrm{rpm}$, steam temperature: $160^{\circ} \mathrm{C}$ ). (a) Comparison of experimental and simulated moisture contents along the dryer, (b) simulated drying rate of each cell per unit contact area, and (c) simulated drying rate of each cell.

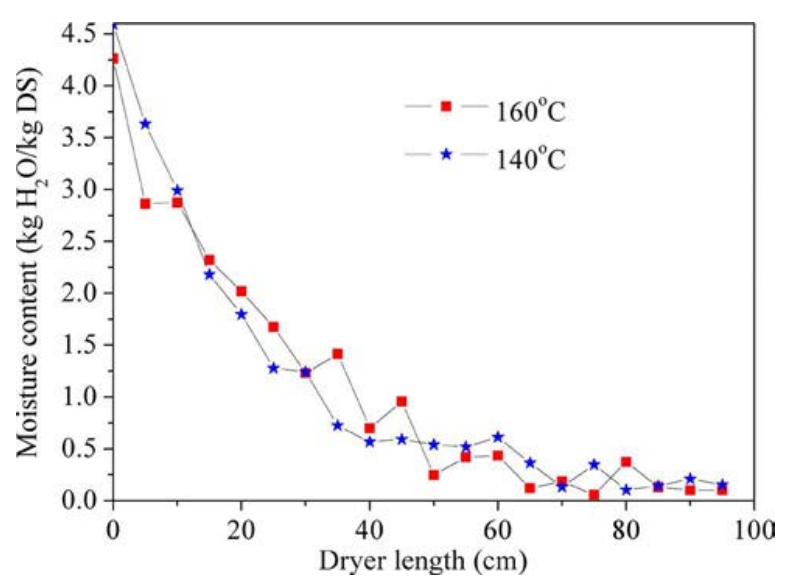

Figure 11. The experimental moisture content during sludge drying in a continuous dryer with different steam temperatures (sludge flow rate: $2 \mathrm{~kg} / \mathrm{h}$, dryer slope: $3^{\circ}$, dryer wall temperature: $160^{\circ} \mathrm{C}$, stirrer speed: $42 \mathrm{rpm}$, steam temperature: 140 and $160^{\circ} \mathrm{C}$ ).

\section{Conclusion}

The coupling model of penetration model and Markov chain developed by Milhé et al. ${ }^{[27]}$ is used to simulate sludge flow and heat transfer in a continuous paddle dryer. Even though strong simplifications were formulated, experimental and simulated drying kinetics are in good agreement for many drying parameters in a satisfactory way within the examined range.

The sewage sludge drying process in a continuous paddle dryer can be divided into three stages: the pasty phase, the sticky phase, and the complete-granular phase. The influences of the drying parameters on the sludge drying kinetics in a continuous paddle dryer were investigated. The sludge flow rate, dryer wall temperature, and dryer slope have remarkable influence on sludge drying in the examined range. However, the stirrer speed and steam temperature have little influence on the drying kinetics in the examined range. Among these which have a remarkable influence on sludge drying, dryer wall temperature has a significant influence on 
the drying rate per unit contact area and dryer slope has a strong influence on the contact area for heat transfer.

\section{Funding}

The research are supported by the National High Technology Research and Development Program of China (No. 2012AA063505), the National Basic Research Program of China 973 (No. 2011CB201506), and the Program of Introducing Talents of Discipline to University (B08026).

\section{Nomenclature}

$1 / h_{\text {total }}$ total heat transfer resistance of sludge drying $\left(\mathrm{m}^{2} \mathrm{~K} \mathrm{~W}^{-1}\right)$

$1 / h_{\mathrm{ws}} \quad$ contact surface resistance $\left(\mathrm{m}^{2} \mathrm{~K} \mathrm{~W}^{-1}\right)$

$1 / h_{\mathrm{sb}} \quad$ penetration resistance of the sludge bulk $\left(\mathrm{m}^{2} \mathrm{~K} \mathrm{~W}^{-1}\right)$

$c_{\mathrm{b}} \quad$ specific heat of the dry bed $\left(\mathrm{J} \mathrm{kg}^{-1} \mathrm{~K}^{-1}\right)$

$t_{\mathrm{R}} \quad$ contact time (s)

$N_{\text {mix }} \quad$ mixing number

$\mathrm{Fr} \quad$ Froude number

$\Delta H_{\text {total }} \quad$ total heat of sorption of sludge $\left(\mathrm{J} \mathrm{kg}^{-1}\right)$

$T_{\mathrm{w}} \quad$ wall temperature (K)

$T_{\text {bed,i }} \quad$ sludge bulk temperature (K)

$m_{\mathrm{V}} \quad$ drying rate per contact area $\left(\mathrm{kg} \mathrm{m}^{-2} \mathrm{~s}^{-1}\right)$

$\Delta T_{\text {bed,i }} \quad$ sludge bulk average temperature increase $(\mathrm{K})$

$X \quad$ moisture content of sludge bulk ( $\mathrm{kg} \mathrm{H}_{2} \mathrm{O} \mathrm{Kg}{ }^{-1} \mathrm{DS}$ )

$\Delta X \quad$ decrement of moisture content of sludge during a contact period $\left(\mathrm{kg} \mathrm{H}_{2} \mathrm{O} \mathrm{Kg}{ }^{-1} \mathrm{DS}\right)$

$c_{\mathrm{w}} \quad$ specific heat of water $\left(\mathrm{J} \mathrm{kg}^{-1} \mathrm{~K}^{-1}\right)$

$\boldsymbol{P} \quad$ matrix of transition probabilities

$P_{i, j} \quad$ transition probability from cell $j$ to cell $i$

$\boldsymbol{S} \quad$ state vector

$S_{\text {feed }} \quad$ vector for feeding of $S$

$R \quad$ recycling coefficient

$\mathrm{Hu}$ holdup of one cell, $\mathrm{kg}$

$\Delta t \quad$ transition time for Markov chain

$t \quad$ time (s)

$t_{\text {critical }} \quad$ critical contact time (s)

$\rho_{\mathrm{b}} \quad$ density of dry bed $\left(\mathrm{kg} \mathrm{m}^{-3}\right)$

$\lambda_{\mathrm{b}} \quad$ effective thermal conductivity of dry bed $\left(\mathrm{W} \mathrm{m}{ }^{-1} \mathrm{~K}^{-1}\right.$ )

$\zeta \quad$ nondimensional drying front position

$\tau \quad$ time (s)

\section{References}

[1] Wang, J.H. On development \& study of urban sludge disposal new technology. China Municipal Engineering 2013, 4, 41-44. (In Chinese).

[2] Deportes, I.; Benoit-Guyod, J.L.; Zmirou, D. Hazard to man and the environment posed by the use of urban waste compost: A review. Science of the Total Environment 1995, 172(2-3), 197-222.

[3] Gantzer, C.; Gaspard, P.; Galvez, L.; Huyard, A.; Dumouthier, N.; Schwartzbrod, J. Monitoring of bacterial and parasitological contamination during various treatment of sludge. Water Research 2001, 35(16), 3763-3770.

[4] McGrath, S.P.; Chang, A.C.; Page, A.L.; Witter, E. Land application of sewage sludge: scientific perspectives of heavy metal loading limits in Europe and United States. Environmental Reviews 1994, 2(1), 108-118.

[5] McGrath, S.P. Metal concentrations in sludges and soil from a long-term field trial. Journal of Agricultural Science 1984, 103, 25-35.

[6] Stevens, J.L.; Northcott, G.L.; Stern, G.A.; Tomy, G.T.; Jones, K.C. PAHs, PCBs, PCNs, organochlorine pesticides, synthetic musks, and polychlorinated n-alkanes in U.K. sewage sludge: survey results and implications. Environmental Science \& Technology 2003, 37(3), 463-467.

[7] Rappe, C.; Andersson, R.; Bonner, M.; Cooper, K.; Fiedler, H.; Howell, F. PCDDs and PCDFs in municipal sewage sludge and effluent from POTW in the state of mississippi, USA. Chemosphere 1998, 36(2), 315-328.

[8] Blanchard, M.; Teil, M.J.; Ollivon, D.; Legenti, L.; Chevreuil, M. Polycyclic aromatic hydrocarbons and polychlorobiphenyls in wastewaters and sewage sludges from the Paris area (France). Environmental Research 2004, 95(2), 184-197.

[9] Yao, J.L.; Wang, H.Y.; Yu, Y.J.; Wang, X.R. The technology assessment and process selection of municipal sewage sludge treatment and disposal technologies. Environmental Engineering 2010, 28(1), 81-84. (In Chinese).

[10] Yang, K.M.; Zhang, C.Y.; Zhang, Y.; Sui, G.S. The way of municipal sludge treatment and disposal and its status analysis of domestic and foreign sludge treatment and disposal. China Resources Comprehensive Utilization 2012, 30(12), 28-31. (In Chinese).

[11] Zhang, H.F.; Xu, Y.; Zeng, Z.Z.; Guo, H.L.; Pan, Y. Municipal sludge treatment way overseas and its enlightenment to China. Environmental Engineering 2010, 28, 434-438. (In Chinese).

[12] Grüter, H.; Matter, M.; Oehlmann, K.H.; Hicks, M.D. Drying of sewage sludge-an important step in waste disposal. Water Science and Technology 1990, 22(12), 57-63.

[13] Fytili, D.; Zabaniotou, A. Utilization of sewage sludge in EU application of old and new methods: A review. Renewable \& Sustainable Energy Reviews 2008, 12(1), 1116-140.

[14] Manara, P.; Zabaniotou, A. Towards sewage sludge based biofuels via thermochemical conversion: A review. Renewable \& Sustainable Energy Reviews 2012, 16(5), 2566-2582.

[15] Kudra, T. Sticky region in drying: Definition and identification. Drying Technology 2003, 21(8), 1457-1469.

[16] Chen, G.H.; Yue, P.L.; Mujumdar, A.S. Sludge dewatering and drying. Drying Technology 2002, 20(4-5), 883-916. 
[17] Schlünder, E.U.; Mollekopf, N. Vacuum contact drying of free flowing mechanically agitated particulate materials. Chemical Engineering and Processing 1984, 18(6), 93-111.

[18] Tsotsas, E.; Schlünder, E.U. Contact drying of mechanically agitated particulate material in the presence of inert gas. Chemical Engineering and Processing 1986, 20(5), 277-285.

[19] Dittler, A.; Bamberger, T.; Gehrmann, D.; Schlünder, E.U. Measurement and simulation of the vacuum contact drying of pastes in a LIST-type kneader drier. Chemical Engineering and Processing 1997, 36(4), 301-308.

[20] Tsotsas, E.; Kwapinska, M.; Saage, G. Modeling of contact dryers. Drying Technology 2007, 24(11), 1469-1480.

[21] Geyaudan, A.; Andrieu, J. Contact drying modeling of agitated porous alumina beads. Chemical Engineering and Processing 1991, 30(1), 31-37.

[22] Farges, D.; Hemati, M.; Laguerie, C.; Vachet, F.; Rousseaux, P. A new approach to contact drying modeling. Drying Technology 1995, 13(5-7), 1317-1329.

[23] Arlabosse, P.; Chitu, T. Identification of the limiting mechanism in contact drying of agitated sewage sludge. Drying Technology 2007, 25(4-6), 557-567.

[24] Deng, W.Y.; Yan, J.H.; Li, X.D.; Wang, F.; Lu, S.Y.; Chi, Y.; Cen, K.F. Measurement and simulation of the contact drying of sewage sludge in a Nara-type paddle dryer. Chemical Engineering Science 2009, 64(24), 5117-5124.

[25] Yan, J.H.; Deng, W.Y.; Li, X.D.; Wang, F.; Chi, Y.; Lu, S.Y.; Cen, K.F. Experimental and theoretical study of agitated contact drying of sewage sludge under partial vacuum conditions. Drying Technology 2009, 27(6), 787-796.

[26] Milhé, M.; Charlou, C.; Sauceau, M.; Arlabosse, P. Modeling of sewage sludge flow in a continuous paddle dryer. Drying Technology 2015, 33(9), 1061-1067.
[27] Milhé, M.; Sauceau, M.; Arlabosse, P. Modeling of continuous sewage sludge drying in a paddle dryer by coupling Markov chain and penetration theory: Influence of contact area estimation. In Proceedings of $5^{\text {th }}$ International Conference on Engineering for Waste and Biomass Valorisation, Rio de Janeiro, Brazil, August 25-28, 2014.

[28] Ferrasse, J.H.; Arlabosse, P.; Lecomte, D. Heat, momentum, and mass transfer measurements in indirect agitated sludge dryer. Drying Technology 2002, 20(4-5), 749-769.

[29] Charlou, C.; Sauceau, M.; Arlabosse, P. Characterisation of residence time distribution in a continuous paddle dryer. Journal of Residuals Science \& Technology 2013, 10(3), 117-125.

[30] Charlou, C.; Milhé, M.; Sauceau, M.; Arlabosse, P. A new methodology for measurement of sludge residence time distribution in a paddle dryer using X-ray fluorescence analysis. Water Research 2015, 69, 1-8.

[31] Milhé, M.; Sauceau, M.; Arlabosse, P. Influence of operating parameters on sewage sludge drying in a paddle dryer: Design of experiments for the determination of hold-up and water content profiles. Drying Technology 2015, 33(11), 1276-1285.

[32] Ferrasse, J.H.; Lecomte, D. Simultaneous heat-flow differential calorimetry and thermogravimetry for fast determination of sorption isotherms and heat of sorption in environmental or food engineering. Chemical Engineering Science 2004, 59(6), 1365-1376.

[33] Tazaki, M.; Tsuno, H.; Takaoka, M.; Shimizu, K. Modeling of sludge behavior in a steam dryer. Drying Technology 2011, 29(14), 1748-1757. 